\title{
SOLVING SOCIAL AND ENVIRONMENTAL ISSUES AND VALUING TOURISTIC POTENTIAL USING GIS-BASED TECHNOLOGY STUDY CASE: BIOUGRA CITY, MOROCCO
}

\author{
Oussama HIMMYa, Hassan RHINANE ${ }^{\mathrm{a}}$, Mehdi MAANAN ${ }^{\mathrm{a}}$ \\ ${ }^{\mathrm{a}}$ Geosciences Laboratory, Faculty of Sciences Ain Chok, Hassan II University, Casablanca, Morocco
}

Commission 4, WG 7

KEYWORDS: GIS, Geographic information system, Multi-Criteria Analysis MCA, Site selection, WWTP, Schools, Cooperatives.

\begin{abstract}
In the last 2 decades, Morocco has known rapid growth of urban transformation followed by significant Population growth, which causes serious environmental problems related to water pollution and scarcity, and social with the deficiencies of infrastructures. And this has been witnessed in the city of Biougra which requires taking serious steps and adopting new projects to solve these issues as soon as possible. And as a reflection of that, this paper takes advantage of Geographic information system (GIS) coupled tools in the first place to locate future sites for building new schools using weighted overlay analysis approach, to improve the education system. And in the second place to choose potential sites for implementing new wastewater treatment plant (WWTP) by adopting multicriteria analysis (MCA). Finally, as a part of saving cultural heritage, and improving the social and economic situation for local citizens, we aim to value cooperative of this region as a replacement of poor touristic quality in the city, by making a track of the existing cooperative and profit from $3 \mathrm{~d}$ modeling as a part of providing the traveler the best possible guide to reach these points of interest and also develop a desktop application for editing and manipulating different types of file related to cooperatives. This study showed successful results by localizing a new site to build a school in the northeastern of the city, and a match between the found site for WWTP and the existing station but with giving a possibility for expansion.
\end{abstract}

\section{INTRODUCTION}

Based on the actual development model, several weaknesses were identified which influence the development trajectory of the country in many fields, for this matter a new model is being adopted to fix all the weaknesses especially related to society and the environment.

An actor citizen in the economy and society is the result of a successful education system based on empowerment, accountability, and motivation. According to UNESCO, Morocco is and will be part of the 25 least developed countries in terms of schooling. Whilst $98 \%$ of second-level students in the public come from poor to middle-class families, wealthy families prefer private schools, also the Moroccan adult literacy rate reached $78 \%$ in 2012 compared to $52 \%$ in 2004. As an act to fight this illiteracy building enough schools and infrastructures is a necessity and urgent matter.

Likewise, an active citizen comes from an environment that guarantees healthy competition and regulates advantages, rents, and privileges to promote efficient productive investment and the reduction of inequalities. Morocco like many other countries is suffering from water scarcity and the generation of wastewater as a considerable threat for natural ecosystems, this brings the subject of making new wastewater treatment plants to recycle wastewater into the environment and even reuse it in agriculture in some cases.

autonomous women, actors of development and exercising their rights for full participation in economic, social, political, and cultural life. This is exactly why it's important to value cooperatives since they're mostly managed by women. It's important to think about valuing these spots for every traveler passing by Biougra city.
Focusing on the above issues, this paper tends to analyze and solve mentioned problems in a local region in Morocco, therefore, locating optimal sites for schools and WWTP requires some rules and guidelines, which is why a multi-criteria analysis based on GIS was developed, in addition to $3 \mathrm{~d}$ modeling to optimize cooperatives tracking.

\section{STUDY AREA}

The study is conducted in Biougra city, the chief town of Chtouka Ait Baha province in the Souss Massa region in Morocco (Figure 1)

Which is a small-scale city covering $10.36 \mathrm{~km}^{2}$, recognized especially by the intensity of agricultural activities that leads to high consumption of underground water.

According to Higher Planning Commission in Morocco, Demography statistics show a significant increase in population over the years, going from 25928 in 2004, to 50465 in 2020, this can be explained by the socio-economic evolution of the region, the natural growth of the urban population, the rural exodus and the extension of the urban perimeters through the integration of some rural localities.

Geographically, Biougra is taking place in The Souss-Massa Basin that is located in the middle west of Morocco, occupying a total surface of $27,000 \mathrm{Km} 2$ with about $21 \%$ of Plain area $(5,700 \mathrm{~km} 2)$ and $79 \%$ of mountain area $(21,300 \mathrm{~km} 2)$. The Anti-Atlas Mountains in the south, the High Atlas Mountains in the north, the Siroua massif in the east, and the Atlantic Ocean in the west are the natural limits of the Souss-Massa River Basin. 
The age of geological formations ranges in depth from Paleozoic to Quaternary, the plain is essentially composed of Quaternary sediments (sands, gravels, and lacustrine limestone) which covers a Paleozoic schistose basement characterized by carbonate and crystalline formations, the opposite of what we have in the north of the basin of Souss Massa and it's only normal since Biougra city is nearest to the Anti-Atlas than High-Atlas.
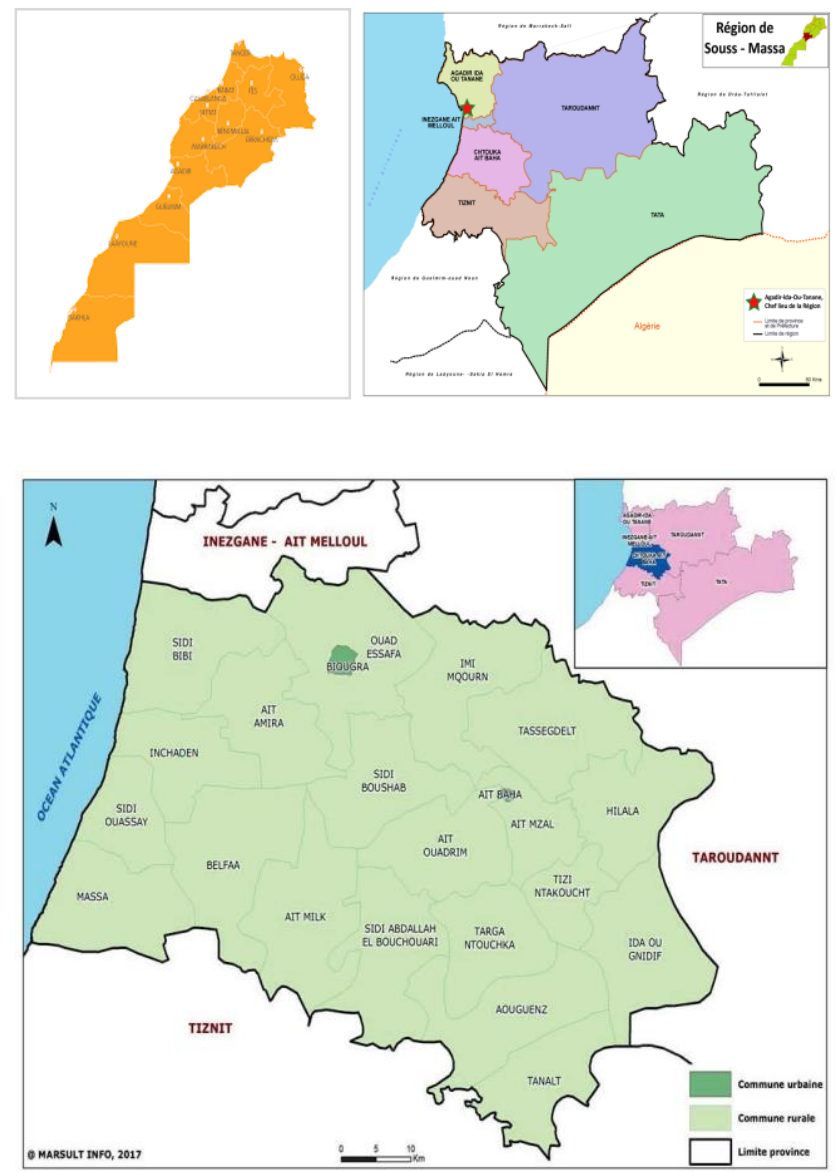

Figure 1. The geographical situation of Biougra city.

\section{MATERIALS AND METHODS}

In this study, a variety of methods were applied depending on each sub-project, although, they all follow the approach of using a geographic information system (GIS), a powerful and ideal tool for performing spatial searches based on map data, with the help of other technologies such as remote sensing, GPS, 3d Modelling and even programming.

The global methodology in Figure 2, resume the workflow of this study which englobes three sub-projects, related to Environment, society, and tourism, Multi-criteria approach is being adopted in both environmental and social project, the difference is manifested in the type of data used either Vector data in the first project and Raster data in the second but sharing Quite the same input data, the methodology and analysis parts are explained in detail in sections 3.1/4.1 and 3.2/4.2.

For the last part concerning the touristic project, it depends on 3 technologies, 3D modeling with Blender, GPS, and Programming with Python, to reinforce cooperatives reputation and activities for the sake of taking the city's tourism to another level, the process will be explained in detail in the sections 3.3 and 4.3.

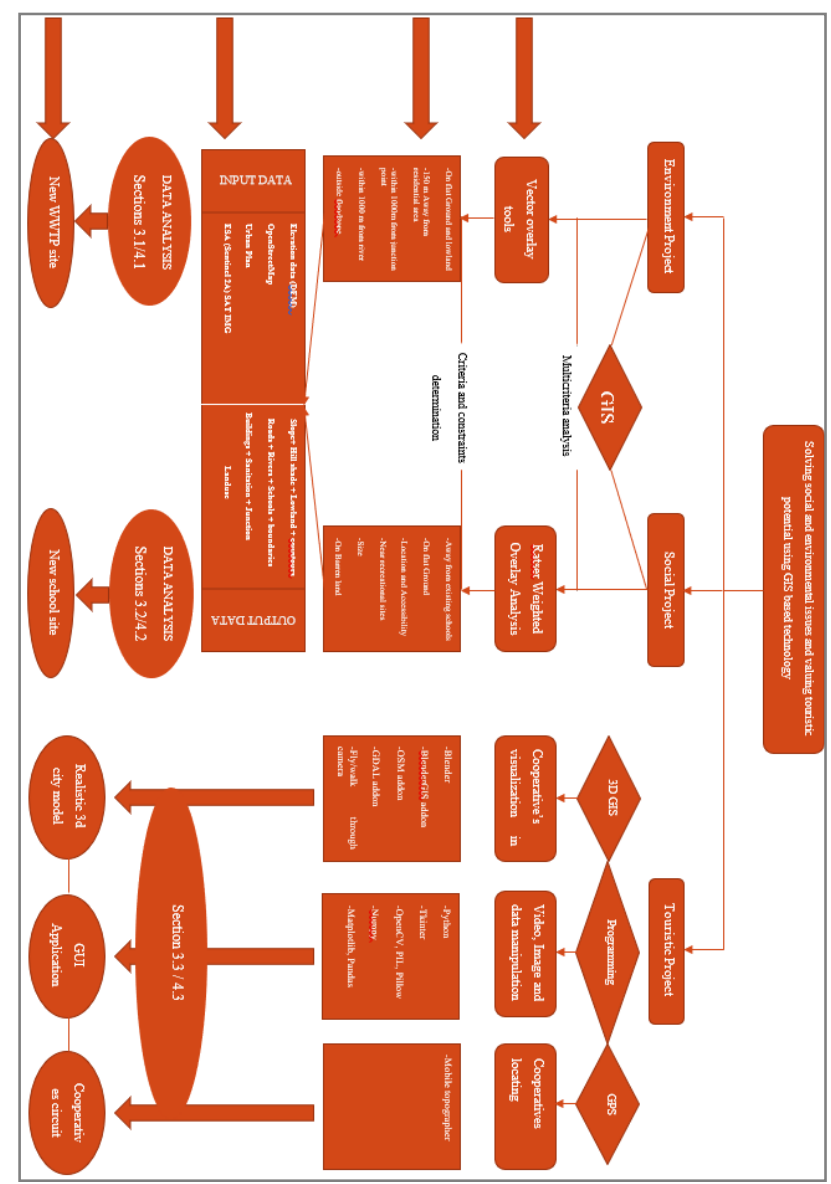

Figure 2. Global methodology of the study.

\subsection{GIS-based MCA for wastewater treatment plant site selection}

The first axis of this study leads to solving an important environmental issue related to the wastewater by locating an optimal site for a new wastewater treatment plant.

This kind of project requires following a multi-criteria analysis to help decision-makers to investigate a wealth of choice possibilities according to multiple criteria and conflicting this objective to select the "the best" alternatives from the number of feasible choice alternatives.

Generally speaking, the so-called criteria are a set of guidelines used as the basis for a decision, here we can talk either about factors and constraints as follows:

a) On flat Ground and lowland to minimize wastewater extraction from underground.

b) $150 \mathrm{~m}$ away from residential areas

c) Within $1000 \mathrm{~m}$ from the junction point

d) Within $1000 \mathrm{~m}$ from a river

e) Outside floodplain 
For this case, the approach depends mostly on dealing with vector data (Figure 4) using a buffer and overlay analysis in the QGIS environment, the goal is to identify the degree of influence and proximity between geographical entities.

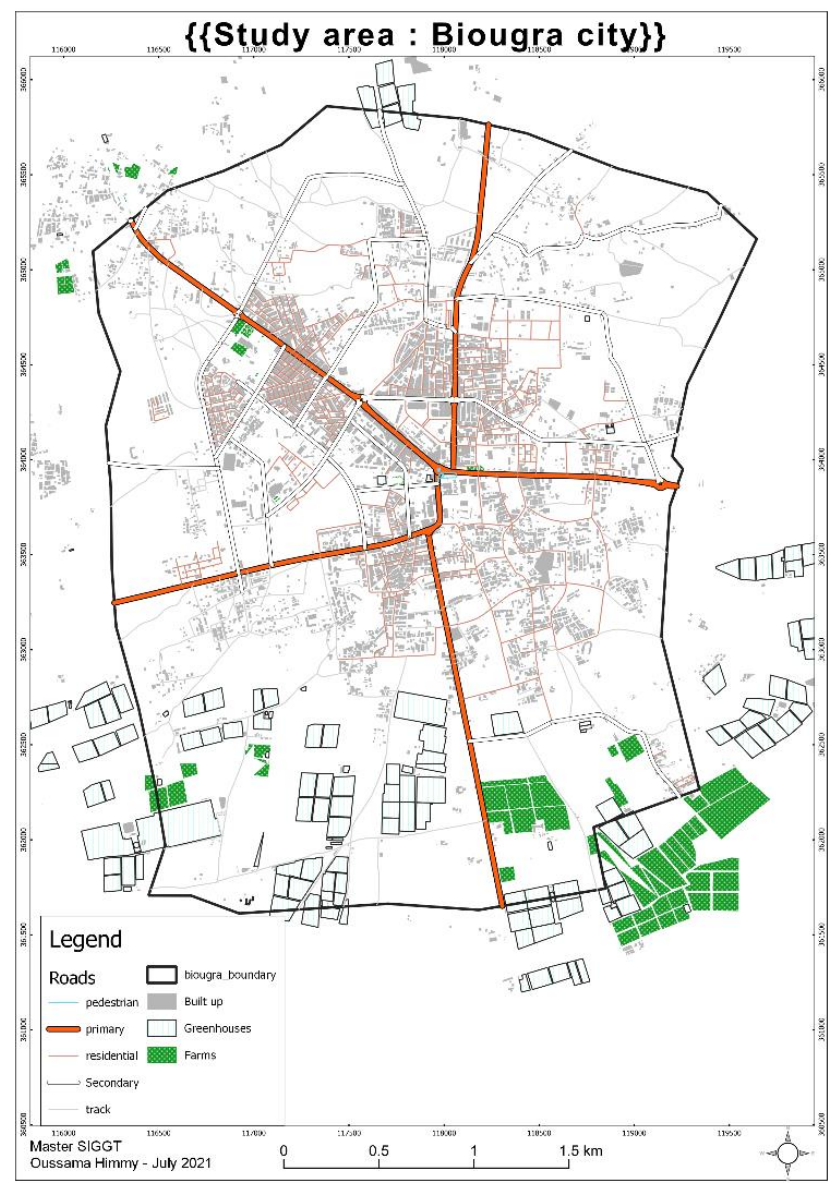

Figure 3. An overview map of the study area and essential data used.

OpenStreetMap is a reliable source to extract the majority of vector data (Figure 3) needed in the study, except buildings and agricultural areas extracted from the AutoCAD format of urban plan and converted later into shapefile format in QGIS environment.

Other than that, some criteria need elevation data to select lowland and also extract slope to select most flat areas.

In this region, rivers are unavailable which is necessary to dismiss treated wastewater. But there are some possibilities to take into consideration revealed later in the study.

\subsection{Spatial MCA for new school site selection}

Another project that depends also on MCA, leads to reinforcing the capacity to hold more students by building a new school and also finding an alternative road accessible by a school bus as a way to reduce the traffic.

Even though, this time a weighted overlay MCA is followed, by giving each criterion a weight revealing a difference of importance for each one. This method depends mostly on raster data.

This project aims to locate a favorite site to build a new school taking into consideration the below: a) As far as possible from existing schools to covers areas that need this infrastructure;

b) Taking into consideration the location and accessibility to roads;

c) Away from steep lands, not only for the sake of children to easily reach the schools, but also to minimize the cost of building the school;

d) Near recreational sites, if it's possible

e) Preferable to have sufficient area for some possible expansions and annexes in the future;

f) The site must be out of the property, where there is a need for landuse;

According to the selected criteria, there is a necessity to have landuse, supervised classification is the key to extract landuse in raster format, for that we used Sentinel $2 \mathrm{~A}$ imagery offering $10 \mathrm{~m}$ resolution good enough to achieve good results after that supervised classification is made in ENVI software following Maximum Likelihood (ML) algorithm. Results are shown in Figure 4.

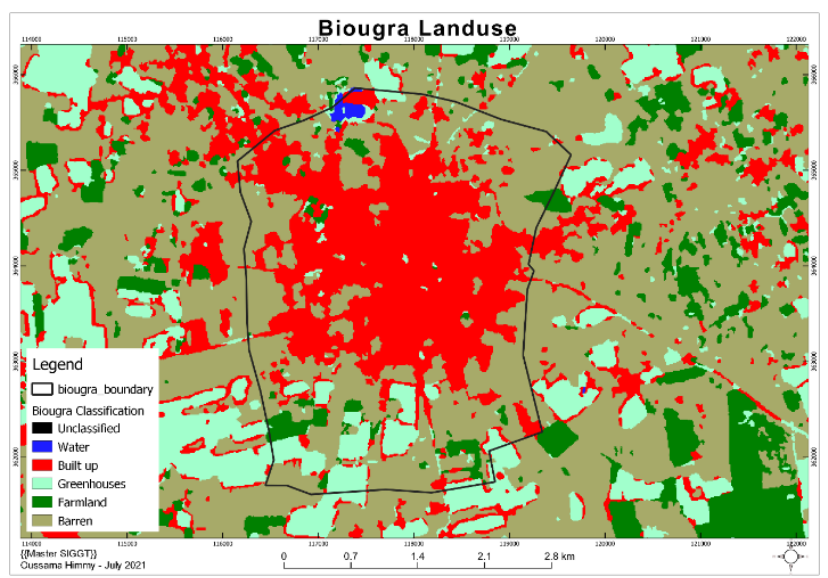

Figure 4. Biougra city landuse map

Taking profit from the previous project data, slope data is already available and schools and main roads are extracted from OpenStreetMap.

After that, a bunch of operations are done to prepare these data for analysis, resumed in Figure 5.

The process starts from collecting data, starting from Sentinel 2A satellite image to extract Land use using supervised classification, DEM to extract slope and Hillshade and schools to calculate Euclidean distance.

The Euclidean distance from schools and Slope will be reclassified to be integrated into a weighted overlay.

The reclassified raster datasets and rasterized layers were overlaid by using a common measurement scale and weight values based on their importance. This is a combination of reclassified raster and rasterized datasets to get suitable sites for a new school.

Different results of each step will be shown in section 4.2. 


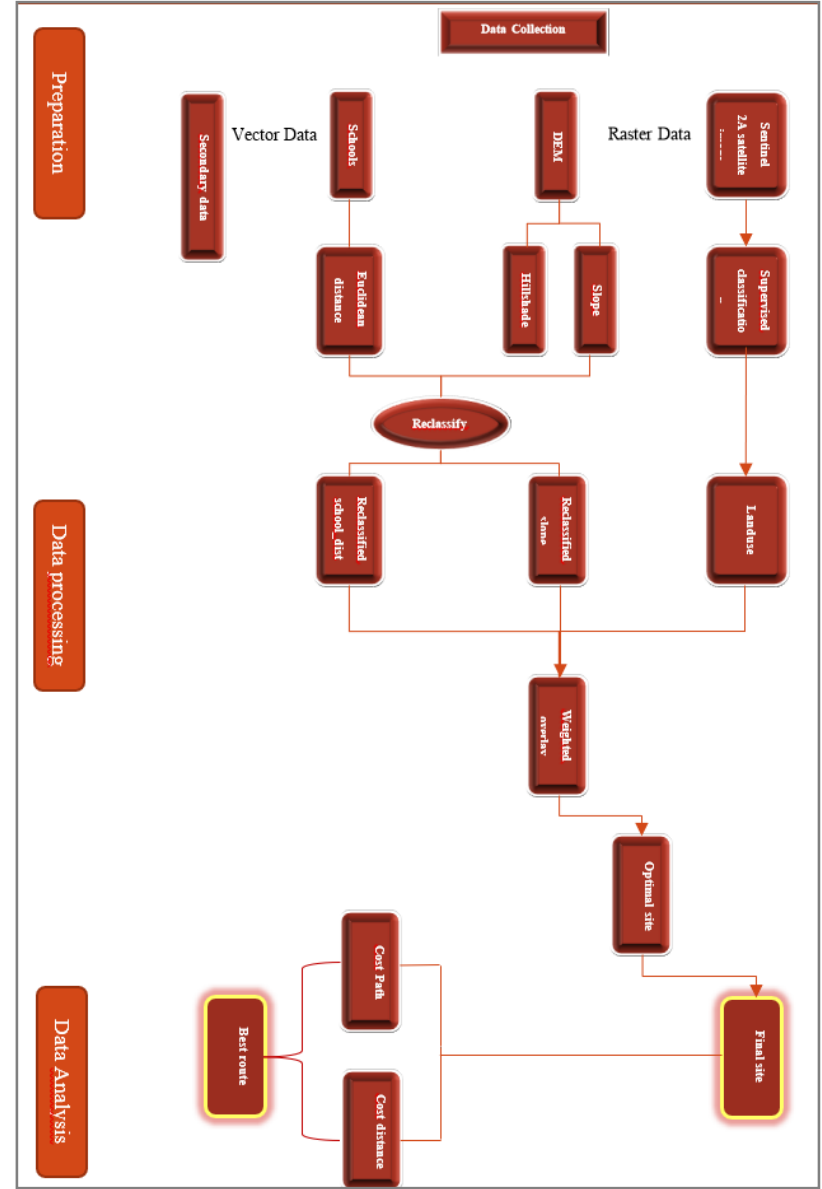

Figure 5. Workflow of schools site selection and new access road finding.

\subsection{Touristic valorization of Biougra city}

As a way to reinforce the touristic potential of a small city like Biougra, we choose cooperatives as a target to the study, to give the traveler a guide of cooperatives potential and activities in the city.

The first thing was to localize cooperatives spots with GPS, followed by converting the GPX file obtained into a GIS environment (shapefile).

The second part was to create a $3 \mathrm{~d}$ model of the city which gives a realistic view of the city and highlights cooperative spots using a blender with addons that support GIS datafile importations, raster images, and even OpenStreetMap.

The combination of these add-ons make it possible to create a $3 \mathrm{D}$ realistic model of the city, by these steps:

1) Importing satellite images from google and clipping in the area of interest, and reprojecting into Merchich CRS (coordinate reference system)

2) Integrating elevation data into the satellite image give the terrain a real topography

3) Extrude the satellite image on the z-axis to make it look like a block.
4) Importing buildings in Merchich CRS. After adding a height attribute to be used in blender to extrude following the z-axis

5) Adding roads in 3D using OSM addon.

6) Texturing both buildings and roads and even the extruded area of a satellite image.

7) Adding an HDR file to give a view of the city in the background.

The final part is to make a desktop application, as a tool for marketing products and editing either photos, videos, and data in a simple way.

For this, we used the Tkinter library that depends on Python Programming Language to create the user interface design of the application following an object-oriented approach.

Besides, we used Other libraries and modules related to images, videos, and data:

- Pandas: for viewing data as data frames.

- NumPy: to deal with multi-dimensional arrays and facilitate advanced mathematical and other types of operations on large numbers of data.

- PIL/PILLOW: for integrating images in UI.

- OpenCV: a library that deals essentially with computer vision, to edit images, with filters, rotations, adjustment.

- Webbrowser: A module Interface for launching and remotely controlling Web browsers.

- Matplotlib: A plotting library the help make graphs.

\section{RESULTS AND DISCUSSION}

\subsection{Expansion possibilities for WWTP}

We can divide the overlay analysis process into 3 levels (Figure $6)$ :

- Level 1: Residential is extracted from Landuse layer, then we applied a buffer of 150 to exclude from Biougra-boundary

- Level 2: Excluding occupied lands (agricultural areas)

- Level 3: Selecting areas within $1000 \mathrm{~m}$ or $500 \mathrm{~m}$ from junction point.

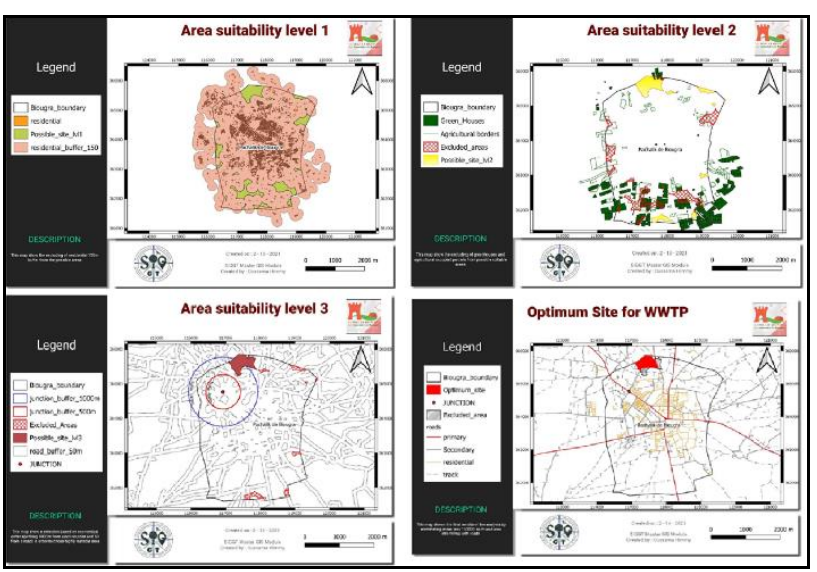

Figure 6. Area suitability analysis 
Following the criteria mentioned before, the overlay analysis revealed a match between the obtained site and the existing wastewater pond as shown in Figure 7.

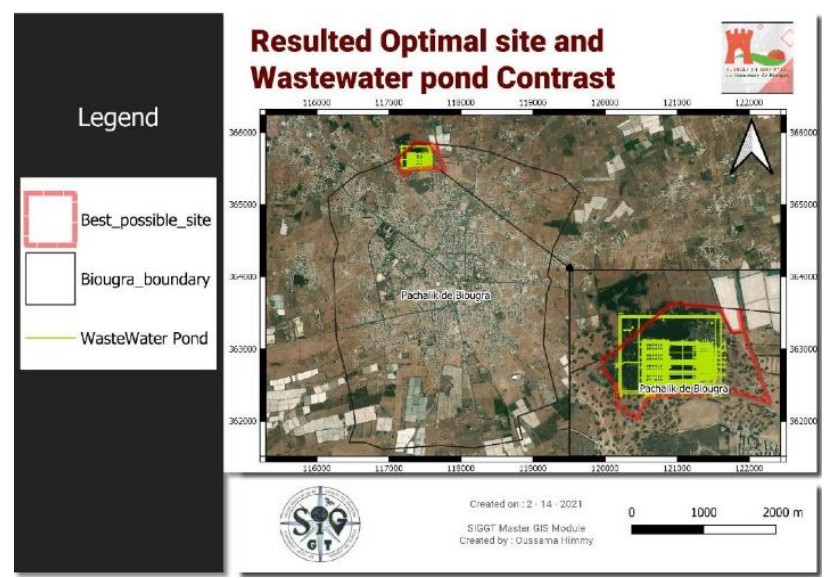

Figure 7. The map shows the match between resulted site and the existing wastewater pond

The problems confronted in this project, are the non-existence of a river near the city where we can launch the treated water to be recycled naturally, and also, we didn't find an alternative site to reduce the pressure applied on the existing station.

One of the possible solutions, is groundwater refill, as a way to recycle treated water, all conditions help this solution to be real by containing groundwater in shallow aquifer and sandy soil that give a fast absorption, but it depends on the quality of treated water.

The actual solution that seems more promising, is to use the river of Souss, even if the river is too far from the city for about $16 \mathrm{Km}$, still, this is the best possible option, since there is a slope for water launching without any pumping cost.

To optimize this option, there is a possibility to link the output of Biougra station with the output of Lqliaa station under construction as shown in Figure 8.

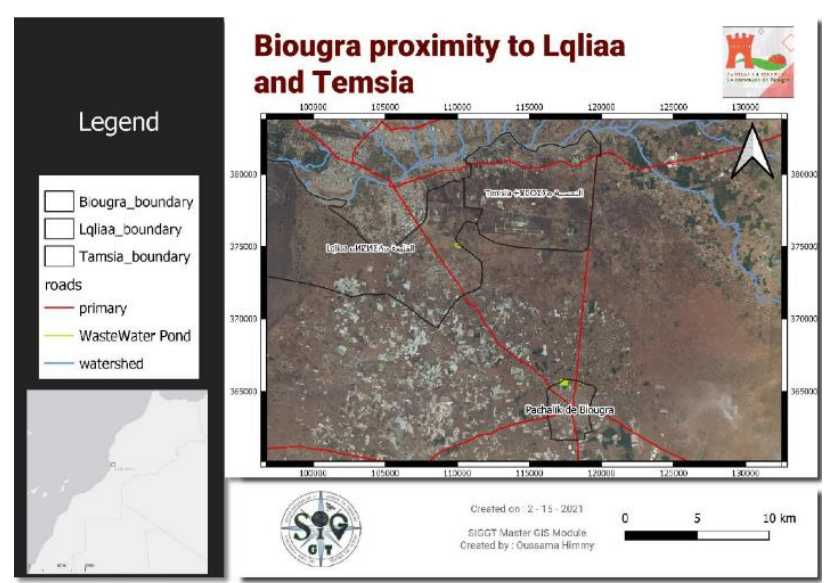

Figure 8. Biougra city proximity to Lqliaa city and Souss River

\subsection{New school optimal site}

With the help of weighted multi-criteria analysis plugin in QGIS, from the Author (Carvalho Neto, R.M. - UFSM and Benedetti, A.C.P. - UFSM) which Displays raster's pixels values to the user, making it possible to assign weights for each raster and grades for each class within each raster, we resulted in a suitable criteria map showing highest suitable areas giving a weight of $25 \%$ to both Slope and Landuse, $50 \%$ for distance from schools.

The next step was to restrict unwanted land-use types like water existing in the wastewater treatment plant from land use and assigning values, fewer values mean that a particular land use type is less suitable.

- Barren land -10

- Built-up -3

- $\quad$ Farms -7

- Greenhouses - 5

The higher the number, the more suitable for a new school.

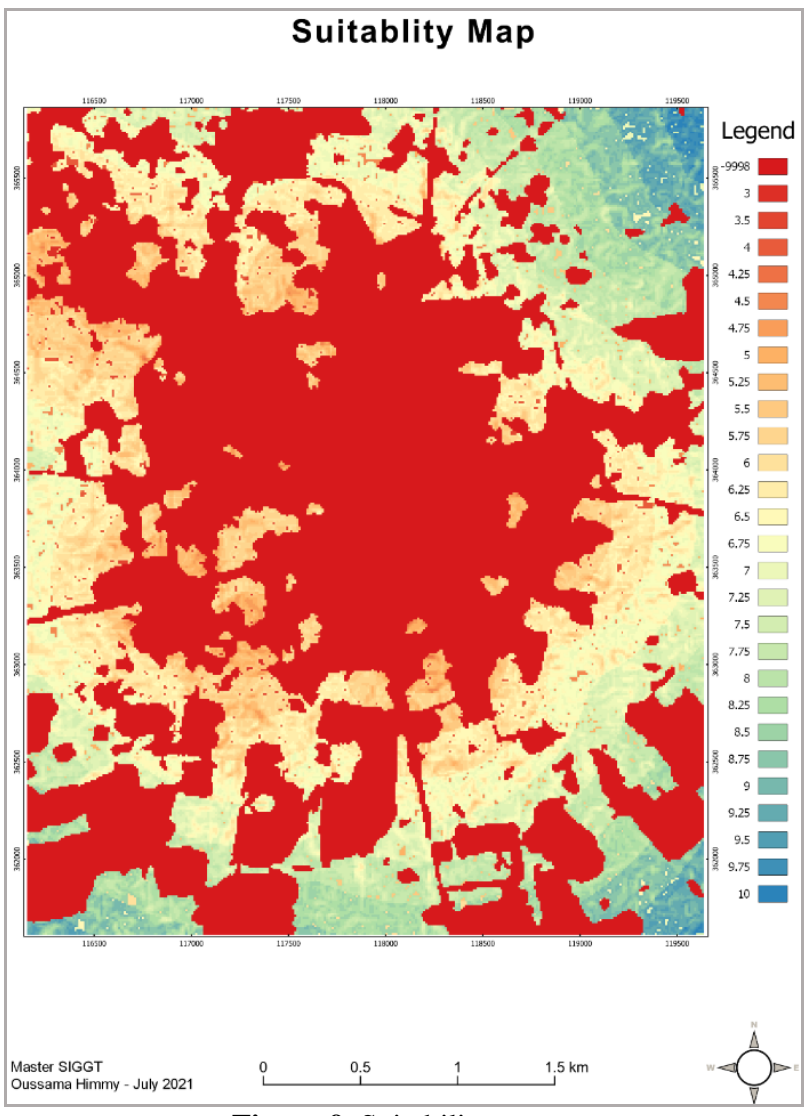

Figure 9. Suitability map

The optimal site is chosen by retrieving cells above the value of 8 and selecting specific are with more than 40,469 square meters as shown with yellow color in Figure 10. 


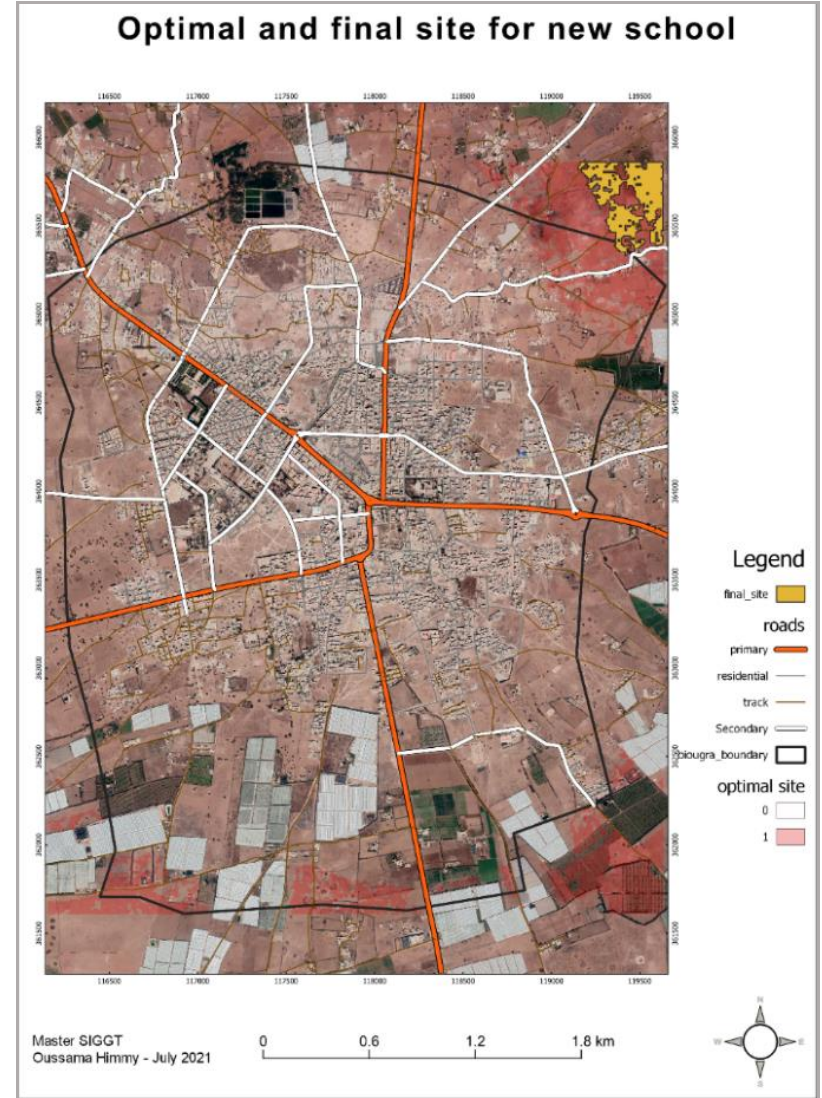

Figure 10. The optimal and final site for building a new school

A site in the north-east of Biougra city a little bit outside the boundary of the urban community is chosen to be the best and final site for build school, in the counterpart sites that are in the south are quite unfavoured to be the host for building a school since it's an area surrounded by greenhouses and farms, which imply the unsafety of this area.

The same process we followed for finding a suitable site, we used classed slope and land use to extract a cost map for building another access road. Just this time low values indicate the area with the least costly to build a road (Figure 11).

What comes next after creating a cost dataset, is performing a cost distance using r.cost in GRASS QGIS, which identifies the cost of traveling through each cell and the final site for building school already identified.

As an output of this tool, we will have a dataset of cumulative cost and a backlink or movement direction dataset that gives the direction of the least costly path from each cell back to the new site for school.

Using the algorithm least-cost path in QGIS, we can find the least cost path with a given cost raster and points that represent layers that contains a new school site (chosen in the final site) and a destination chosen to be the intersection between 2 secondary roads near the site, the results are shown in Figure 12 .

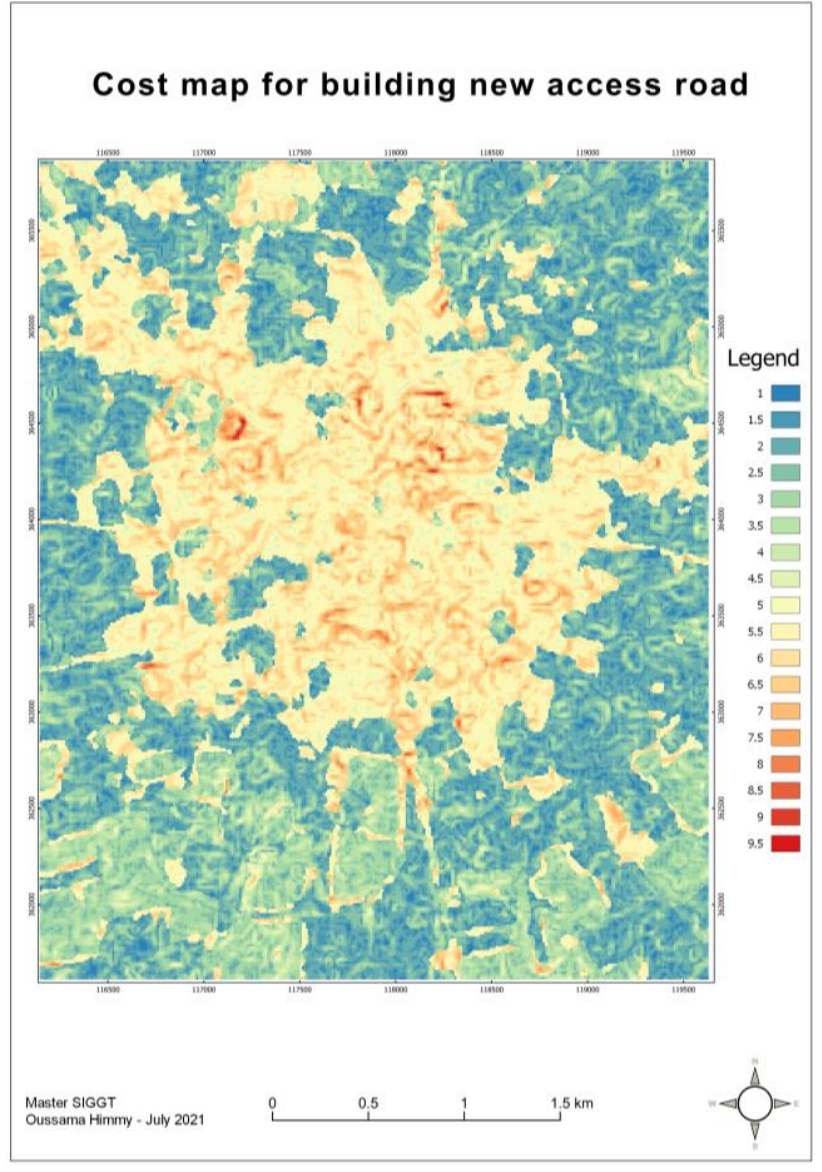

Figure 11. Cost map for building new access road

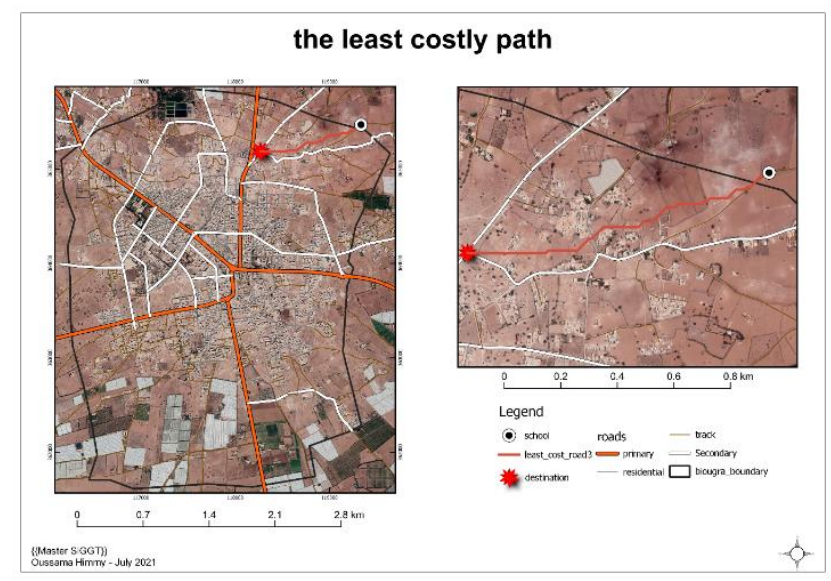

Figure 12. Least costly access road

The set objective has been successfully done, and the most important thing is that the adopted site for a new school is too far from the wastewater treatment plant. Accomplishing this project will reduce the pressure upon other schools and as shown in maps there is a population living around the chosen site, which will make them benefit from this new school, and avoid going to $\mathrm{Al}$ Fallah school that is far from about $1.5 \mathrm{~km}$. 


\subsection{D modeling and Programming for cooperatives valorization}

After consulting the General Directorate of Taxes in Biougra city, we collected a list of 10 cooperatives for this study as shown in the table below:

\begin{tabular}{|c|c|c|c|c|}
\hline Name & Adresse & Type & Community & $\begin{array}{l}\text { Specialty } \\
\text { products }\end{array}$ \\
\hline $\begin{array}{c}\text { Coop } \\
\text { ELFAKIT }\end{array}$ & Road Hassan II & AGRICULTURAL & $\begin{array}{c}\text { Biougra-Oued } \\
\text { Essafa }\end{array}$ & Dates \\
\hline $\begin{array}{l}\text { Coop ATIG } \\
\text { ISFANE }\end{array}$ & DR OURTI & AGRICULTURAL & $\begin{array}{c}\text { Biougra-Oued } \\
\text { Essafa }\end{array}$ & Flowers \\
\hline $\begin{array}{c}\text { Coop } \\
\text { TIZRATINE }\end{array}$ & DR AIT DAOUD & AGRICULTURAL & Biougra M & Argane \\
\hline $\begin{array}{l}\text { Coop AL } \\
\text { ANWAR OF } \\
\text { HOUSING }\end{array}$ & $\begin{array}{l}\text { ALFALAH- } \\
\text { BOUALAGA }\end{array}$ & HOUSING & & - \\
\hline Coop ALQODS & $\begin{array}{l}\text { №13 AVENU } \\
\text { ABDELKRIM } \\
\text { ELKHATTABI } \\
\text { HAY LES } \\
\text { CHALETS }\end{array}$ & HOUSING & Biougra M & - \\
\hline $\begin{array}{c}\text { Coop } \\
\text { KHOYOT } \\
\text { ELFANE }\end{array}$ & $\begin{array}{l}\text { HAY LES } \\
\text { CHALETS } 1\end{array}$ & SEWING & Biougra M & sewing \\
\hline $\begin{array}{c}\text { Coop } \\
\text { ANNAJMA } \\
\text { ADAHABIA }\end{array}$ & $\begin{array}{l}N^{\circ} 77 \text { BLOC B } \\
\text { HAY LES } \\
\text { CHALETS - } \\
\text { BIOUGRA- }\end{array}$ & AGRICULTURAL & Biougra M & Argane \\
\hline $\begin{array}{c}\text { Coop SAMAK } \\
\text { BIOUGRA }\end{array}$ & $\begin{array}{c}\mathrm{C} / O \text { NUM N }^{\circ} 18 \\
\text { SERIE P } \\
\text { MARCHE DE } \\
\text { POISSON - } \\
\text { BIOUGRA- }\end{array}$ & FISHING & Biougra M & Fish \\
\hline $\begin{array}{l}\text { Coop RYAD } \\
\text { ESSAADA }\end{array}$ & $\begin{array}{c}\text { No5 RUE AL } \\
\text { BARID HAY AIT } \\
\text { EL HOUCINE OU } \\
\text { ALI }\end{array}$ & HOUSING & Biougra M & - \\
\hline Coop AMAL & $\begin{array}{c}\text { No02 IMM } \\
\text { ABOUDRAR LOT } \\
\text { TIRSTE } 1\end{array}$ & HOUSING & Biougra M & - \\
\hline
\end{tabular}

Table 1. List of cooperatives in Biougra city

The map below reveals the result of the cooperative's locations by using GPS coordinates.

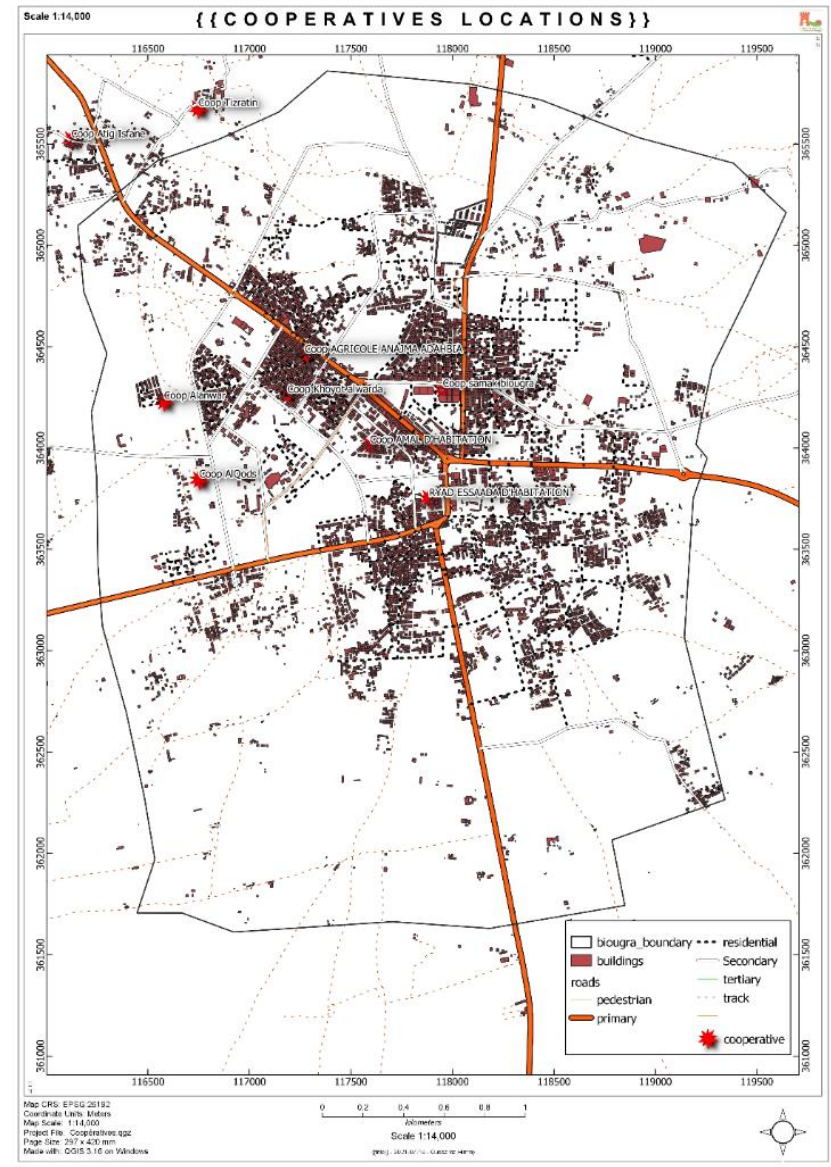

Figure 12. Cooperatives location in the city of Biougra
The result of 3D modeling using Blender is shown in Figure 13, which seems not fully complete, even though the main reason was to make a fly-through animation as a guide to easily know the location of cooperatives as shown in Figure 14.

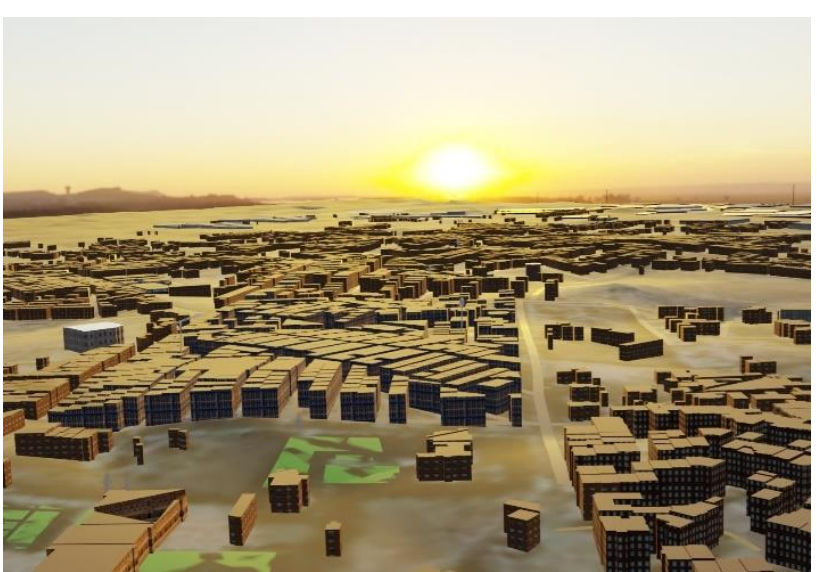

Figure 13. Biougra city $3 \mathrm{~d}$ model captured from Blender

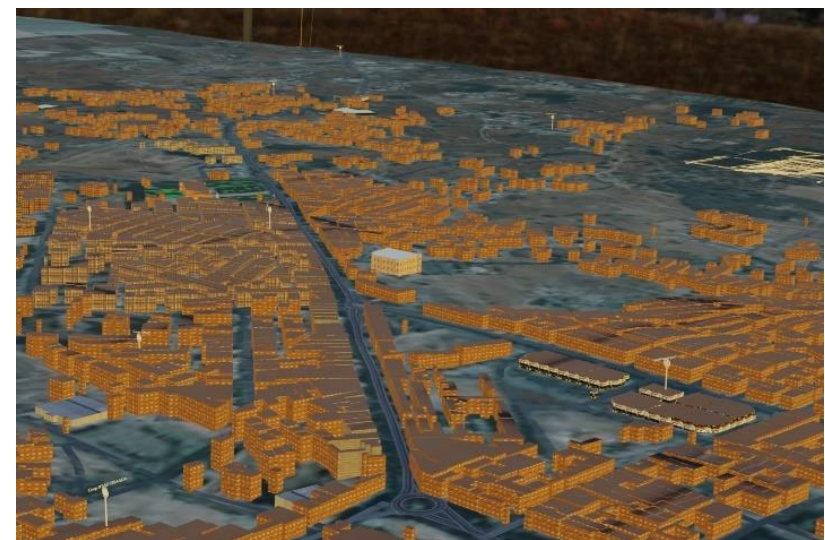

Figure 14. Cooperatives location in Biougra city $3 \mathrm{~d}$ model

The last part of this project was the desktop application developed with Python programming language in addition to other libraries mentioned before.

The User interface was made by Tkinter to look as simple as possible to be easily manipulated by cooperative workers.

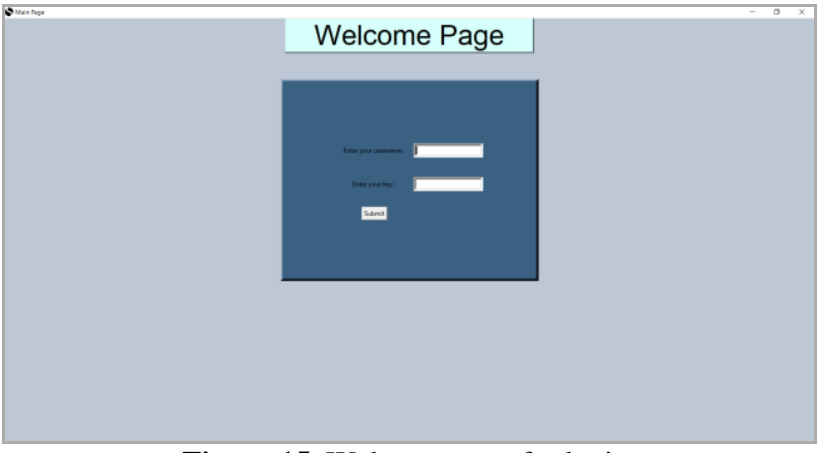

Figure 15. Welcome page for login 
The application gives access to 3 sub-applications:

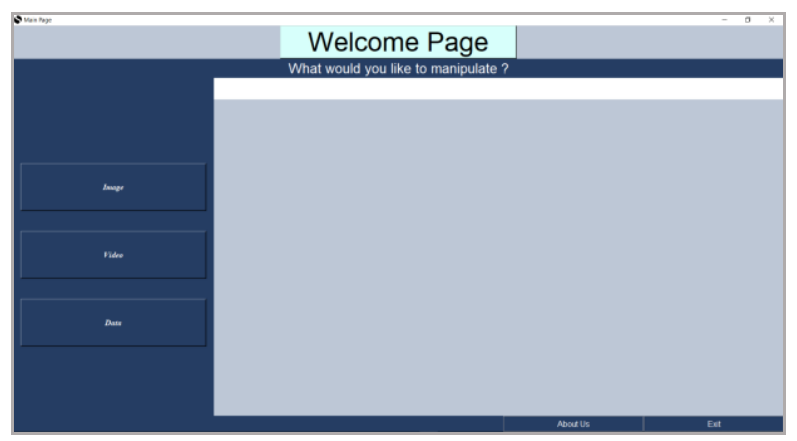

Figure 16. Sub Apps

- Image app that lets the user do some basic editing from cropping, applying some filters, drawing, rotating, and adjusting.

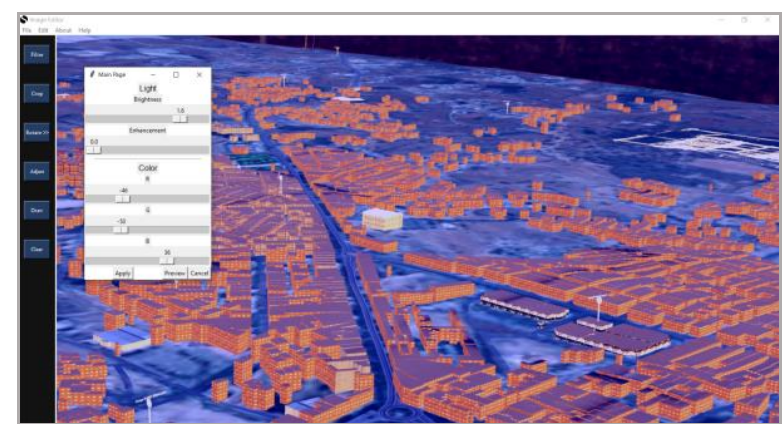

Figure 17. Image App interface

- Data App: for visualizing Data frames in the form of the tree view.

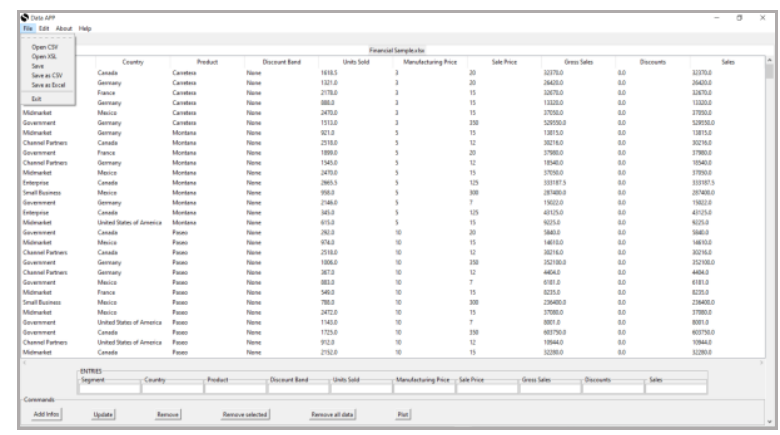

Figure 18. Data visualization

- Video App: For playing videos

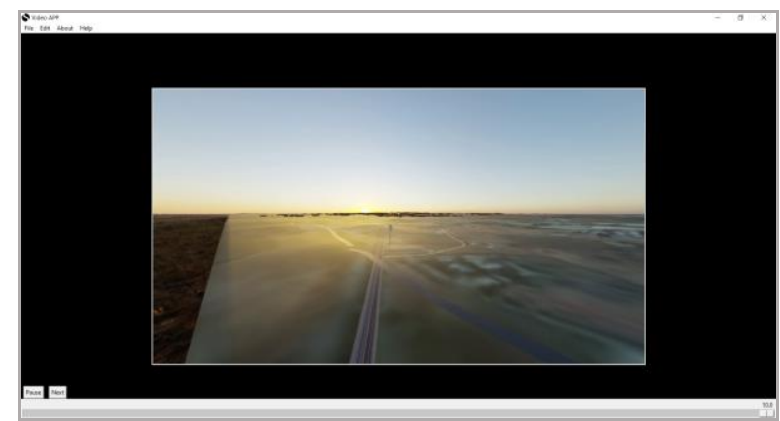

Figure 19. Video player

\section{CONCLUSION}

As an evaluation for this project, we feel that it succeeds in Solving big problems related to the Environment and Society and valorizing the touristic potential of the city.

With the help of GIS technology and Programming, it's now less complicated to make decisions and develop the situation for the future.

By this technology we used in this project we can convince the authorities in the country to invest in this field more and more as a way to follow the new development model that our country will follow in upcoming years.

Even though we feel that this study can be improved and why not someone will come and make it even better.

\section{REFERENCES}

M. Hssaisoune, S. Boutaleb, M. Benssaou, B. Bouaakkaz, and L. Bouchaou (2016) Physical Geography, Geology, and Water Resource Availability of the Souss-Massa River Basin.

\section{REGIONAL MONOGRAPHY SOUSS MASSA (2015, 2019).}

M. Cavur, H.S. Duzgun, S. Kemec, D. C. Demirkan, The International Archives of the Photogrammetry, Remote Sensing and Spatial Information Sciences, Volume XLII-1/W2, 2019 Evaluation, and Benchmarking Sensors, Systems and Geospatial Data in Photogrammetry and Remote Sensing, 1617 Sept. 2019, Warsaw, Poland, LAND USE AND LAND COVER CLASSIFICATION OF SENTINEL 2-A: ST PETERSBURG CASE STUDY.

Hamidi Abdul Aziz, Amin Mojiri Wastewater Engineering: Advanced WastewaterTreatment Systems, p 2-3-4.

Combe M, El Hebil A (1977) Vallée du Souss, in Ressources en eau du Maroc, tome3. Domaines atlasique et sud atlasique. Notes et Mémoires du Service Géologique, Maroc.231 :169201

Xiangnan, L., 2005. GIS Spatial Analysis Principle and Method.

Leake, C. and Malczewski, J., 2000. GIS and Multicriteria Decision Analysis. Journal of the Operational Research Society, Vol 51(2).

Malczewski, J., 2007. GIS - based multicriteria decision analysis: a survey of the literature. International Journal of Geographical Information Science, Vol volume 20(20): pp. 703-726.

Hina Zaidi, 2018. From QGIS to Blender: Visualizing and Creating Georeferenced 3D models. 